\title{
POTENSI INTOLERANSI KEAGAMAAN SISWA SEKOLAH DI JAWA DAN SULAWESI
}

\author{
Imam Tholkhah \\ Peneliti Puslitbang Pendidikan Agama dan Keagamaan \\ Badan Litbang dan Diklat Kementerian Agama Republik Indonesia \\ Jl. MH Thamrin No. 06 Jakarta Pusat \\ puslitbangpenda@yahoo.co.id
}

\begin{abstract}
This particular writing describes research upon the interest of students towards religious education and a developing potency for intolerance in public and religious schools. The research indicates that the students show a rather high interest towards religious teaching in schools. Teachers still can make religious teachings attractive. On the other hand, a minor amount of students still appear to be less interested in religious teachings. The minority stated that this is because of the monotonic and unattractive ways in which the teacher in conveys the information. Fortunately, the majority of the students continue to apply a high level of tolerance to religious teachings. This fact shows that religious teachers are still capable of teaching religious education that is relevant to the national education standards. However, there still remain students who lack tolerance towards religious teaching. There are indications that they provide support towards groups who apply discrimination, lack of respect, and intolerance to other groups with different practices or religion. Even though the level of intolerant students is low, the fact that it could expand remains possible, so precaution is still needed. If this particular potential for expansion is taken lightly, it may become a threat towards the nation because it has a potential to be a source of religious conflict. The development of multicultural understanding and tolerance in public or religious schools is one way to resolve this problem.
\end{abstract}

Keyword: Tolerance, Intolerance, Religion

\begin{abstract}
Abstrak
Tulisan ini merupakan temuan penelitian yang menggambarkan minat siswa terhadap pendidikan agama dan potensi intoleransi keagamaan siswa yang berkembang di sekolah dan madrasah. Temuan itu menunjukkan bahwa minat siswa terhadap pendidikan agama sangat tinggi. Dan para gurupun masih menyampaikan pendidikan agama dengan menarik. Sebagian kecil siswa kurang berminat mempelajari agama. Mereka mengatakan metode mengajar guru agama tidak menarik atau membosankan. Mayoritas siswa di sekolah memiliki pandangan keagamaan yang toleran. Fakta ini menunjukkan bahwa guru agama mampu mengajarkan pendidikan agama sesuai dengan standar nasional pendidikan. Hanya saja terdapat sebagian siswa yang memiliki potensi intoleransi keagamaan. Di antara indikasinya adalah mereka memberikan dukungan pada kelompokkelompok yang berprilaku diskriminatif, tidak memberikan penghargaan, tidak menghendaki eksistensi pihak lain yang memiliki paham atau aliran keagamaan berbeda. Meskipun jumlah siswa yang intoleran minoritas di sekolah, pertumbuhan potensi intoleransi ini perlu dicegah, agar tidak berkembang luas. Kalau potensi ini dibiarkan berkembang, maka lama kelamaan dapat menjadi sumber konflik keagamaan yang dapat mengancam persatuan dan kesatuan bangsa. Di antara cara mencegahnya adalah melalui pengembangan wawasan multikultural dan pengembangan budaya toleransi di sekolah dan madrasah.
\end{abstract}

Kata Kunci: Toleransi, Intoleransi, Keagamaan

Naskah diterima 10 Januari 2013. Revisi pertama, 21 Februari 2013. Revisi kedua, 7 Maret 2013 dan revisi terahir 02 April 2013. 


\section{PENDAHULUAN}

Tulisan ini akan membincangkan persoalan potensi intoleransi keagamaan di sekolah. Kajian potensi intoleransi keagamaan ini penting dilakukan dengan tiga alasan: Pertama, informasi potensi intoleransi di sekolah perlu dikaji lebih lanjut, terutama yang terkait dengan akar persoalan yang melatar belakanginya, dan kemungkinan mengatasinya. Potensi intoleransi keagamaan di sekolah kalau tidak memperoleh perhatian akan menjadi sumber gerakan radikal faham keagamaan. Gerakan semacam ini pada skala tertentu dapat berubah menjadi sumber konflik sosial, mengganggu kerukunan umat beragama dan selanjutnya melemahkan persatuan dan kesatuan bangsa. Kedua, informasi potensi intoleransi keagamaan di sekolah umum perlu dipublikasikan, agar pihak-pihak yang terkait dapat mengetahui dan kemudian peduli untuk memberikan kontribusi untuk mengatasi atau memecahkan masalah intoleransi di sekolah umum. Ketiga, secara substansial intoleransi keagamaan bertentangan dengan tujuan pendidikan agama sebagaimana tertuang dalam peraturan pemerintah no 55 tahun 2007, dan tidak selaras dengan tujuan pendidikan nasional sebagaimana tercantum dalam UU no 20 tahun 2003.

Topik utama kajian ini membahas masalah intoleransi keagamaan yang berkembang di sekolah umum. Pertanyaan penelitiannya adalah: 1) Seberapa besar minat siswa sekolah dan madrasah terhadap pendidikan agama; 2) Dalam aspek apa saja pandangan siswa sekolah menggambarkan adanya potensi intoleransi keagamaan dan 3) Seberapa besar potensi intoleransi keagamaan siswa di sekolah berkembang. Tujuan kajian ini adalah untuk menggambarkan potensi intoleransi keagamaan siswa Sekolah Menengah Atas (SMA) dan sekolah Menengah Kejuruan (SMK). Manfaat kajian ini adalah untuk bahan masukan kebijakan untuk meningkatkan mutu pendidikan agama di sekolah dan madrasah untuk mengurangi potensi intoleransi keagamaan para siswa. Hasil kajian ini juga bermanfaat untuk para pimpinan dan guru agama di sekolah dan madrasah untuk meningkatkan mutu pendidikan agama yang rahmatan lil alamin. Selain itu kajian ini juga bermanfaat untuk bahan pustaka dan kajian-kajian lebih lanjut tentang paham keagamaan para siswa di lingkungan sekolah umum.

Metode penelitian ini bersifat kuantitatif, yang diselenggarakan bulan Nopember 2011. Lokasi penelitian di 12 propinsi, yang mencakup 133 kabupaten/kota, dengan jumlah responden 804 siswa pada 201 SMA, MA, dan SMK, negeri dan swasta. Pemilihan responden dilakukan dengan metode acak bertingkat, mulai dari memilih wilayah kabupaten/kota, sekolah/madrasah dan memilih siswa laki-laki dan perempuan yang beragama Islam dan non Islam secara proporsional. Kesalahan margin eror sebesar 3,45\% pada tingkat kepercayaan 95\%. Pengumpulan data dilakukan melalui wawancara terstruktur, oleh sejumlah peneliti lapangan yang telah dilatih sebelumnya. Data dianalisa dengan diskriptif kuantitatif. ${ }^{1}$

\section{KAJIAN PUSTAKA}

Dewasa ini bangsa Indonesia masih dihadapkan pada tantangan berupa adanya kecenderungan potensi sikap dan prilaku intoleransi yang tinggi, ${ }^{2}$ baik dalam hubungan antar kelompok umat beragama atau interen umat beragama. ${ }^{3}$ Gagal menghadapi tantangan ini dapat melahirkan konflik-konflik keagamaan sebagaimana terjadi pada kurun waktu tahun 1990 an sampai dengan tahun 2000 an, yang memakan banyak korban jiwa dan harta ben-

${ }^{1}$ Pembahasan penelitian ini merupakan sebagian dari hasil penelitian yang berjudul Studi Paham Keagamaan pada SMA, SMK dan Madrasah di Jawa dan Sulawesi, yang dilakukan oleh sebuah tim peneliti Puslitbang Pendidikan Agama dan Keagamaan tahun 2011.

${ }^{2}$ Tim Peneliti Puslitbang Penda. 2011, Penelitian Tentang Paham Keagamaan GPAI di Sekolah, Jakarta, Puslitbang Pendidikan Agama dan Keagamaan.

${ }^{3}$ Ismail Hasani, et al. 2011. Radikalisme Agama di Jabodetabek dan Jawa Barat: Implikasinya terhadap Jaminan Kebebasan Keragaman/Berkeyakinan. Jakarta: Setara Institute. Tim Survey. 2011. Laporan Penelitian, Ancaman bagi ideologi Negara Melalui Radikalisme Agama. Jakarta: Lembaga Penelitian Uhamka. 
da, termasuk hancurnya obyek-obyek ritual keagamaan seperti Gereja dan Masjid. ${ }^{4}$

Informasi berbagai tentang potensi sikap intoleransi bagi sebagian kelompok penganut agama masih sering muncul di media cetak dan elektronik, forum-forum diskusi, dan penelitian lembaga swadaya masyarakat. ${ }^{5}$ Dalam masyarakat Indonesia masih terdapat tindakan-tindakan anggota kelompok, atau organisasi penganut agama yang bersifat intimidasi, ancaman kekerasan, penyegelan dan pelarangan atau perusakan pembangunan rumah ibadah, perusakan properti, diskriminasi, pernyataan dan penyebaran kebencian atas nama agama terhadap kelompok yang berbeda faham keagamaannya. ${ }^{6}$ Beberapa hasil penelitian menunjukkan bahwa sikap intoleransi sudah terbentuk sejak di sekolah menengah atas. $^{7}$

\section{Pengertian Toleransi dan Intoleransi}

Istilah toleransi berasal dari kata "toleran" (Inggris: tolerance; Arab: tasamuh) yang berarti ambang batas ukur untuk penambahan atau pengurangan yang masih diperbolehkan. Secara Etimologi, toleransi adalah kesabaran, ketahanan emosional, dan kelapangan dada. Sedangkan menurut istilah, toleransi berarti bersifat atau bersikap menenggang (menghargai, membiarkan, membolehkan) pendirian

${ }^{4}$ M. Atho Mudzhar. 2005. "Pendidikan Agama Di Sekolah Umum Dalam Perspektif Multikultural", dalam Puslitbang Penda. 2005. Pengembangan Agama Berwawasan Multikultural. Jakarta: Puslitbang Pendidikan Agama dan Keagamaan.

${ }^{5}$ Abdurrahman Mas'ud (ed). 2011. Kerukunan Umat Beragama Dalam Sorotan - Refleksi dan Evaluasi 10 (sepuluh) Tahun Kebijakan dan Program Pusat Kerukunan Umat Beragama, Jakarta: Pusat Kerukunan Umat Beragama, Sekretariat Jenderal Kemenag.

${ }^{6}$ Tim Peneliti Puslitbang Kehidupan Keagamaan. 2011. Laporan Tahunan Kehidupan Keagamaan Di Indonesia 2011, Jakarta, Puslitbang Kehidupan Keagamaan.

${ }^{7}$ Ahnaf. 2012. Dalam Ahmad Suaedy. 2013. "Strategi Moderasi Atas Kecenderungan Radikalisme Agama di Indonesia: Tanggapan Terhadap Hasil Penelitian Radikalisme Agama di Kalangan Mahasiswa Perguruan Tinggi Agama." Makalah Seminar. Jakarta: Puslitbang Pendidikan Agama. (pendapat pandangan, kepercayaan, kebiasaan $\mathrm{dsb}$ ) yang berbeda dan atau yang bertentangan dengan pendiriannya. Toleransi dapat dibudayakan dalam kehidupan bermasyarakat Indonesia, karena bangsa Indonesia memiliki akar keagamaan dan budaya toleransi yang kokoh. ${ }^{8}$ Pembudayaan toleransi mengarah pada terciptanya sebuah bentuk pikiran, sikap, prilaku, tindakan untuk bersabar, menahan diri, menghargai, menghormati, tidak mengganggu atau melecehkan pihak-pihak lain, siapapun jenis kelaminnya, sukunya, bangsanya, warna kulitnya, adat istiadatnya, bahasanya, agamanya, pendapatnya serta keyakinannya. ${ }^{9}$

Lawan kata toleransi adalah intoleransi atau tidak toleran. Pengertian intoleransi adalah sikap-sikap yang tidak menghargai pendirian pihak lain yang berbeda. Sikap intoleransi dapat mengarah pada prilaku kekerasan baik fisik maupun non fisik yang tidak mengenal belas kasihan, seperti melakukan pelecehan, diskriminasi, intimidasi, pengrusakan, penyerangan, pengusiran, dan pembunuhan. Sikap-sikap intoleransi ini secara teoritik dapat menjadi salah satu faktor yang dapat melahirkan konflik keagamaan. Konflik keagamaan adalah tindak kekerasan fisik atau non fisik yang melibatkan dua kelompok penganut faham keagamaan yang berbeda, dengan melibatkan simbol-simbol keagamaan. Simbol-simbol keagamaan ini dapat bersifat fisik seperti tempat ibadah, kitab suci, pakaian khas kelompok agama, atau identitas kelompok agama lain. Simbol-simbol keagamaan yang non fisik seperti pernyataan-pernyataan penganut agama, lagu-lagu atau yel-yel yang khas bermakna agama. ${ }^{10}$

${ }^{8}$ Mohammad Atho Mudzhar. 2011. Islam In A Globalized World - The Challenges of Human Rights, Law, and Interfaith Harmony, Jakarta: Badan Litbang dan Diklat Kementerian Agama, h. 79 -87. Dalam Bahrul Hayat. 2012. Mengelola Kemajemukan Umat Beragama. Jakarta: Saadah Cipta Mandiri. H. 93-102

9 Imam Tholkhah. 2010. Ahlak Pendidikan Islam, Jakarta, Titian Pena, h. 116.

${ }^{10}$ Imam Tholkhah (ed), (2002). Konflik Sosial Bernuansa Agama Di Indonesia, Jakarta, Puslitbang Kehidupan Beragama, Departemen Agama RI, 
Dari aspek pengalaman historis, konsep toleransi telah berkembang sejak masa Nabi Muhammad diangkat menjadi rasul sekitar tahun $610 \mathrm{M}$. Pada waktu itu antara Nabi Muhammad dan Waraqa bin Naufal, tokoh Nasrani, telah menjalin persahabatan melalui berbagai dialog keagamaan, yang saling mengakui kebenaran keyakinan masing-masing dan menghormati keyakinan sahabatnya. Peristiwa lain, ketika Raja Najasy dari Ethiopia meninggal dunia, Nabi meminta para sahabat untuk menyembahyangkan, pada hal belum ada kejelasan apakah Raja Najasy itu seorang muslim atau bukan. Bahkan pada peristiwa lain ketika Nabi melakukan dialog dengan delegasi dari Najran yang beragama kristen di Masjid Madinah dan kemudian delegasi tersebut memohon izin untuk menjalankan kebaktian di luar, Nabi menyarankan agar delegasi tersebut melakukan kebaktian di dalam Masjid. ${ }^{11}$

Pengalaman historis masa Nabi Muhammad yang sangat terkenal bernuansa toleransi adalah adanya kesepakatan Piagam Madinah. Di antara isinya adalah bahwa orang Muslim dan orang Yahudi mempunyai hak yang sama untuk saling tolong menolong dan mempertahankan agamanya. Bahkan ketika pembebasan Mekkah pada tahun $630 \mathrm{M}$ oleh kaum Muslimin, Nabi melindungi kaum Nasrani di Makkah untuk mempertahankan agamanya dan beribadah sesuai dengan agamanya. Demikian juga ketika kaum Muslimin menguasai Yerussalem, Khalifah Umar menandatangani perjanjian yang di antara isinya adalah Khalifah akan menjamin jiwa, harta, gereja-gereja dan salib-salib mereka untuk tidak dihancurkan. Umat Kristen diberikan hak untuk tetap memeluk agamanya dan keselamatan mereka harus mendapatkan jaminan. ${ }^{12}$

Dari perspektif ajaran normatif, konsep toleransi yang ditawarkan dalam pendidikan Islam adalah bahwa setiap penganut agama harus meyakini kebenaran agamanya, tetapi dalam waktu yang bersamaan juga harus mem-

${ }^{11}$ Malik Muhammad. 2002. "Pluralisme Agama dan Toleransi Dalam Islam," Dialog - Jurnal Penelitian dan Informasi Keagamaan, No 54 Th.XXV, Desember

${ }^{12}$ Ibid. biarkan atau menghormati penganut agama lain meyakini kebenaran agamanya. ${ }^{13}$ Pendidikan Islam mengajarkan bahwa tidak ada paksaan bagi seseorang untuk menganut agama ( al Baqoroh, 2: 256). Dalam memaknai ayat ini sebagian ahli menyatakan bahwa janganlah memaksa seseorang untuk memeluk Islam. Islam adalah agama yang jelas dan gamblang tentang semua ajaran dan bukti kebenarannya, sehingga tidak perlu memaksakan seseorang untuk masuk ke dalamnya. ${ }^{14}$ Dalam pendidikan Islam juga diajarkan bahwa realita sosial tentang keanekaragaman keyakinan umat manusia memang telah menjadi kehendak Tuhan. Dinyatakan dalam Surat Yunus, 10: 99, yang artinya "Dan jikalau Tuhanmu menghendaki, tentulah beriman semua orang yang dimuka bumi seluruhnya. Maka apakah kamu (hendak) memaksa semua manusia supaya mereka menjadi orang-orang yang beriman?. Bahkan dalam pendidikan agama Islam juga di ajarkan agar sesama manusia untuk berbuat baik dan berlaku adil. Rujukannya adalah surat al Mumtahanah, 60: 8, yang artinya: Allah tidak melarang kamu untuk berbuat baik dan berlaku adil terhadap orang-orang yang tiada memerangimu karena agama dan tidak (pula) mengusir kamu dari negerimu; Sesungguhny a Allah menyukai orang 2 yang berlaku adil. ${ }^{15}$

Lebih lanjut, pendidikan agama Islam di sekolah juga mengajarkan bahwa realita kemajemukan bangsa ini merupakan sunnatullah yang tidak bisa dihindari. Rujukannya al Quran surat al Hujurat, 49: 13, yang artinya: "Hai Manusia, sesungguhnya kami menciptakan kamu dari seorang laki-laki dan seorang perempuan, dan menjadikan kamu berbangsa-bangsa dan bersuku-suku supaya kamu saling kenal mengenal. Sesungguhnya orang yang paling mulia diantara kamu di sisi Allah ialah orang yang paling taqwa di antara kamu.

Ayat tersebut menyiratkan bahwa ajaran Islam mengakui adanya keragaman yang meliputi suku bangsa, bahasa, budaya dan agama.

${ }^{13}$ ImamTholkhah. 2010. Ahlak dan Pendidikan Islam. Jakarta: Titian Pena. h.116121.

${ }^{14}$ Imam Tholkhah. 2008. Menghiasi Diri dengan Ahlak Mulia. Jakarta: Al Ghazali. h. 65-67

${ }^{15} \mathrm{Ibid}$. 
Semua keragaman ini memiliki asal usul yang sama dan memiliki tujuan hidup yang sama yaitu menjadi individu yang mulia di sisi Tuhan. ${ }^{16}$ Melalui keragaman inilah manusia diperintahkan untuk saling mengenal satu sama lain dan memahami serta mengakui perbedaan tersebut sebagai fitrah Tuhan. Salah satu makna penting adanya keanekaragaman dalam ciptaan Allah ini bukanlah untuk mendorong pertentangan dan perang, melainkan agar manusia saling kenal mengenal, sebagaimana di isyaratkan dalam al Quran surat al Maidah, 5: 48 , yakni saling berlombalah untuk mewujudkan masyarakat utama. ${ }^{17}$

Pendidikan Islam mengajarkan perlunya sikap toleransi terhadap sesama manusia yang memeluk agama non Islam. Ayat-ayat al Quran yang menjadi rujukan adalah Surat al Maidah, 5: 48, yang artinya ...untuk setiap umat di antara kamu, Kami berikan aturan dan jalan yang terang. Kalau Allah menghendaki, niscaya kamu di jadikan Nya satu umat (saja), tetapi Allah hendak menguji kamu terhadap karunia yang telah diberikanNya kepadamu, maka berlomba-lombalah berbuat kebajikan. Hanya kepada Allah kamu semua kembali, lalu diberitahukannNya kepadamu terhadap apa yang dahulu kamu perselisihkan.

Ayat di atas menjelaskan bahwa, setiap umat memiliki aturan dan jalannya sendiri, dan setiap umat harus yakin terhadap ajaran agamanya sendiri, karena Allah pasti akan menguji atas apa yang telah ia berikan. Setiap umat beragama harus berlomba-loma dalam kebajikan. Setiap umat beragama harus menghormati perbedaan yang memisahkan mereka. Tidak di anjurkan bagi penganut agama untuk menghakimi keyakinan agama lain, karena di hari akhir nanti, Allah akan menunjukkan apa yang diperselisihkan. ${ }^{18}$

${ }^{16}$ Abd.Fatah Wibisono. dkk. 2010. Islam Rahmatan Lil Alamiin- Buku Rujukan Guru PAI Sekolah Menengah Pertama (SMP). Jakarta: Direktorat Pendidikan Agama Islam,

${ }^{17}$ Hanief Saha Ghafur. dkk. 2010. Islam Rahmatan Lil Alamiin- Buku Rujukan Guru PAI Sekolah Menengah Atas (SMA), Sekolah Menengah Kejuruan (SMK). Jakarta: Direktorat Pendidikan Agama Islam, h. 100 - 126

${ }^{18}$ Hanief Saha Ghafur. dkk. 2010. Islam Rahmatan Lil 'alamiin, Buku Rujukan Guru PAI Sekolah Dasar (SD).

\section{Akar Intoleransi Keagamaan}

Pengalaman konflik sosial bernuansa keagamaan, antar umat beragama dan interen umat beragama memiliki akar historis yang panjang. Antara 1095 - 1272 telah terjadi perang Salib antara kelompok Islam dan Kristen, yang memakan korban besar di kedua belah pihak. ${ }^{19}$ Perang ini tentu ikut mempengaruhi adanya jarak sosial antara umat Islam dan Kristen di seluruh dunia. Jarak sosial antar penganut Islam dan Kristen di Indonesia juga dipertajam pengalaman historis perjuangan nasionalisme umat Islam melawan penjajah Belanda. Meskipun perjuangan tersebut merupakan konflik sosial antara penjajah dengan yang dijajah, tetapi karena penjajah Belanda beridentitas penganut Kristen, dan kebijakan pemerintah Belanda dinilai oleh pejuang muslim lebih mendukung pengembangan Kristen, ${ }^{20}$ maka pengalaman ini telah memperlebar jarak sosial antara komunitas Islam dengan Kristen. ${ }^{21}$ Jarak sosial ini akan mempersubur tumbuhnya sikap dan prilaku intoleransi antar penganut paham keagamaan Islam dan Kristen yang dalam kondisi tertentu dapat melahirkan konflik keagamaan.

Sejak sebelum Indonesia merdeka, ketegangan dan bahkan konflik keagamaan sering muncul ke permukaan. ${ }^{22}$ Seiring dengan adanya persistiwa-peristiwa yang bersifat politis untuk memperoleh kekuasaan, seperti pemilihan anggota dewan, pemilihan kepala desa, walikota, bupati, gubernur dan presiden. ${ }^{23}$ Pengalaman konflik keagamaan antar umat

Jakarta: Direktorat Pendidikan Agama Islam

${ }^{19}$ Graham E. Fuller. 2010. A World Without Islam. New York: Back Bay Books, h. 95- 116.

${ }^{20}$ Imam Tholkhah. 2006. "Peran STAIN Dalam Pendidikan Islam," dalam Mudji Raharjo, Quo Vadis Pendidikan Islam, Malang: UIN-Malang Press, h.73 - 88

${ }^{21}$ Imam Tholkhah. 2003. "Pemuda dan Tantangan Global." Dalam Fadhal AR Bafadhal (ed), Pemuda dan Pergumulan Nilai pada Era Globa. Jakarta: Badan Litbang Agama dan Diklat Keagamaan, h. 1 - 39

${ }^{22}$ ImamTholkhah. 2008. Manusia, Agama dan Perdamaian. Jakarta: Al Ghazali, h. 107-110

${ }^{23}$ Imam Tholkhah. 2001. Anatomi Konflik Politik di Indonesia - Belajar dari Ketegangan Politik Varian Madukoro. Jakarta: PT Grafindo Persada 
Islam dan Kristen Indonesia telah banyak memakan korban, termasuk hancurnya berbagai objek ritual keagamaan seperti Gereja dan Masjid yang terjadi sekitar tahun 1990 an sampai dengan tahun 2000 an. Di beberapa daerah konflik sosial bernuansa keagamaan juga muncul sewaktu-waktu dalam bentuk protes, intimidasi, pengrusakan tempat perjudian, minuman keras, dan pelacuran yang dinilai bertentangan dengan ajaran agamanya. ${ }^{24}$

Konflik keagamaan akan meningkat lebih cepat jika benturan antara kedua kelompok penganut agama memperoleh dukungan yang meluas dari kelompok faham keagamaan radikal-intoleran, yakni kelompok keagamaan yang dalam menjalankan agamanya dengan cara-cara kekerasan, ekstrim, anarkis, terhadap penganut faham agama yang berbeda dengan kelompoknya. ${ }^{25}$ Kelompok keagamaan radikal-intoleran itu dapat berkembang di berbagai komunitas, termasuk komunitas sekolah, ${ }^{26}$ kapan saja, dari semua komunitas penganut agama yang berbeda. ${ }^{27}$ Hal ini karena, sikap-sikap yang keras dan ekstreem, sering menjadi salah satu instrumen kelompok keagamaan radikal-intoleran untuk mencapai tujuan tertentu. ${ }^{28}$

Dalam interen umat Islam sendiri, intoleransi keagamaan juga memiliki akar sejarah lama, yakni dimulai sejak lahirnya kelompok

${ }^{24}$ Neng Dara Affiyah. Dkk (eds). Gerakan Keislaman Pasca Orde Baru - Upaya Merambah Dimensi Baru Islam. Jakarta: Badan Litbang Agama dan Diklat Keagamaan, h. $23-62$

${ }^{25}$ Imam Tholkhah. 2002. "Krisis Sosial Dan Kebangkitan Gerakan Radikalisme Keagamaan Era Reformasi Di Indonesia." Dalam Dialog- Jurnal Penelitian dan Informasi Keagamaan, no. 54 Th XXV, Desember, 13 - 26

${ }^{26}$ Imam Tholkhah. 2011. "Peta Guru Pendidikan Agama di Sekolah." Dalam , Pendidikan Agama dan Keagamaan - Reinventing Pendidikan Islam Unggul dan Kompetitif. Jakarta: Puslitbang Pendidikan Agama dan Keagamaan, h. $151-166$

${ }^{27}$ Herlina (terj). 2005. Guard The Religious Conflicts In Strengthening National Integration. Jakarta: Balitbang dan Diklat Kementerian Agama, h. 28 - 30

${ }^{28}$ Imam Tholkhah \& Neng Dara Affiyah. (eds) Gerakan Keislaman Pasca Orde Baru - Upaya Merambah Dimensi Baru Islam. Jakarta: Badan Litbang Agama dan Diklat Keagamaan, h. $23-63$
Khawarij pada masa Khalifah Ali Bin Abi Thalib. Perbedaan faham keagamaan antara kelompok Khawarij dengan kelompok Ali Bin Abi Thalib, telah mengakibatkan khalifah Ali Bin Abi Thalib di bunuh oleh kelompok Khawarij, sebuah kelompok Islam yang memiliki faham keagamaan radikal - intoleran. ${ }^{29}$

Dalam perkembangan lebih lanjut akar intoleransi keagamaan komunitas muslim sering dikaitkan dengan berkembangnya gerakan faham keagamaan Salafiyah yang dipelopori oleh Ibnu Taimiyah (1263-1328), yang kemudian dikembangkan oleh gerakan Wahabi yang dimotori oleh Muhammad Abd Wahab (1703-1787). Di antara inti faham keagamaan Salafiyah adalah memurnikan ajaran Islam, mengajak kembali pada Al Quran dan Sunnah Nabi sebagaimana yang diamalkan oleh generasi awal umat Islam. Ajaran Islam yang bercampur dengan bid'ah, khurofat, takhayul dan memuja kuburan para wali dan tokoh agama dikecam oleh gerakan faham Wahabi. Seiring dengan perkembangan modernisasi, kolonialisasi, dan globalisasi, varian faham keagamaan Salafiyah berkembang di berbagai belahan dunia termasuk Indonesia. Sebagian varian gerakan Salafiyah menjadi gerakan sosial dan pendidikan yang inklusif dan sebagian menjadi gerakan dakwah dan politik yang radikal, anti sekularisme, anti neo-kolonialisme, anti neo-imperialisme, anti liberalisme dan bersifat transnasional. Setelah perang dunia I, ketika nasionalisme merebak, sebagian kelompok Salafiyah di berbagai negara termasuk Indonesia, juga mengembangkan organisasi sosial politik yang bersifat nasional. ${ }^{30}$ Di era sekarang, gerakan Salafiyah mengangkat kembali tema-tema anti pornografi, pelacuran, perjudian dan minuman keras di masyarakat sebagaimana

${ }^{29}$ Atho Mudzhar. 2012. "Akar Kekerasan Dan Kekeliruan Dalam Pemahaman Sejarah Dan Keagamaan Islam". Makalah Seminar. Jakarta: Direktorat Pendidikan Agama Islam Kementerian Agama. Dan Azyumardi Azra. 2012. "Radikalisme Keagamaan dan Deradikalisasi:" Peran Aparat Negara, Pemimpin Agama dan Guru Untuk Kerukunan Umat Beragama. Makalah Seminar. Jakarta: Direktorat Pendidikan Agama Islam

${ }^{30}$ Imam Tholkhah. 2008. Manusia, Agama dan Perdamaian. Jakarta: Al Ghazali, h. 105 - 110. 
telah dikobarkan oleh gerakan Salafiah pada era perang Paderi 1784-1803. ${ }^{31}$

Kelompok faham keagamaan radikal-intoleran mencuat secara dramatis sejak adanya krisis ekonomi, sosial budaya dan politik menjelang runtuhnya Orde Baru, hingga awal pemerintahan Reformasi. Pada masa Orde Baru kelompok faham keagamaan radikal- intoleran juga berkembang, tetapi tidak dapat tumbuh di permukaan secara leluasa. Ketika fenomena kelompok radikal-intoleran muncul maka pemerintah segera meredam dengan berbagai cara. ${ }^{32}$

Banyak faktor mengapa kelompok keagamaan radikal - intoleran muncul ke permukaan dan melahirkan konflik. Secara sederhana dapat dikelompokkan ke dalam dua faktor, yakni faktor kepentingan keagamaan dan faktor kepentingan non keagamaan: Faktor kepentingan keagamaan yang sering menjadi pemicu konflik sosial bernuansa keagamaan sejak masa lalu adalah, benturan misi penyiaran agama, pendirian rumah ibadah, perkawinan antar penganut agama yang berbeda, penodaan agama, penyelenggaraan hari besar agama yang tidak kondusif. Selain itu, pada setiap agama memiliki doktrin dalam kitab suci yang dipahami oleh penganutnya berbeda-beda. ${ }^{33}$ Dari sinilah, lahir aliran-aliran penganut faham keagamaan yang berbeda dalam satu agama. Tiadanya penghayatan dan pengamalan ajaran toleransi antara aliran paham keagamaan dapat saling salah menyalahkan, saling sesat menyesatkan dan saling cela mencela bahkan saling menyerang. ${ }^{34}$ Sedangkan faktor non

${ }^{31}$ Imam Tholkhah \& Neng Dara (eds). Gerakan Keislaman Pasca Orde Baru - Upaya Merambah Dimensi Baru Islam Jakarta: Badan Litbang dan Diklat Kementerian Agama, h. 7 - 19.

${ }^{32}$ Tholkhah, Imam. 2002. "Memupuk Kerukukunan dan Menepis Konflik Berbasis Masyarakat," Dalam Harmoni-Jurnal Multikultural dan Multi Religius, voluume 1, nomor 4, Oktober - Desember, h. 18 - 23

${ }^{33}$ Imam Tholkhah. 2002. "Pendahuluan." Dalam Imam Tholkhah\& Fanani (eds). Gerakan Islam Klasik \& Kontradiksi Faham Keagamaan. Jakarta: Balitbang Agama dan Diklat Keagamaan, h. 1 - 10

${ }^{34}$ Imam Tholkhah. 2004. "Membangun Kualitas Kerukunan Umat Beragama." Dalam Harmoni- Jurnal keagamaan yang dapat memunculkan kelompok radikal-intoleran adalah adanya benturan kepentingan ekonomi dan politik antar kelompok faham keagamaan yang berbeda. ${ }^{35}$

\section{Kajian Potensi Toleransi Siswa Sekolah Terdahulu}

Dalam era peradaban global dan era reformasi ini, berbagai varian faham keagamaan baik yang bersifat inklusif atau eksclusif, radi$\mathrm{kal}$ atau moderat, fundamentalis atau liberal dapat secara mudah berkembang di Indonesia. Karena itu tidak mengherankan apabila dewasa ini faham keagamaan yang bersifat radikalintoleran juga masuk dalam komunitas sekolah. Hasil Angket Direktorat Pendidikan Agama Islam terhadap pengurus Rohis SMA dan SMK Jawa dan Sumatera telah menunjukkan adanya indikasi berkembangnya potensi sikap intoleransi di sekolah, meskipun diketahui bahwa potensi toleransi siswa sekolah masih cukup tinggi. ${ }^{36}$ Dari hasil angket tersebut terlihat $90 \%$ dari pengurus Rohis SMA/SMK yang menjadi responden bersedia untuk berteman dengan orang yang berbeda agama di sekolah. Berarti ada sekitar $10 \%$ siswa yang memiliki potensi intoleran mengenai pertemanan ini. Kemudian terdapat $85 \%$ dari responden Rohis SMA/SMK yang bersedia bertetangga dengan orang-orang yang berbeda agama, dan sisanya $15 \%$ tidak bersedia bertetangga dengan orang-orang yang berbeda agama. Angket juga menunjukkan bahwa $88 \%$ pengurus Rohis SMA/SMK menyatakan tidak bersedia untuk merusak gereja yang sudah memiliki izin pendirian, selebihnya $12 \%$ bersedia untuk merusak gereja, meskipun gereja sudah memiliki izin. Dalam hal gereja yang tidak memiliki izin, terdapat 60\% dari pengurus rohis yang menjadi

Multikultural dan Multireligius, Volume III, Nomor 12, h. 61 72

${ }^{35}$ Imam Tholkhah. 2005. Mewapadai Konflik Antar Umat Beragama. Jakarta: Badan Litbang dan Diklat Kementerian Agama

${ }^{36}$ Table hasil angket yang di edarkan oleh Direktorat Pendidikan Agama Islam pada acara pembinaan Rohis SMA/SMK yang mewakili pulau Jawa, dan Sumatra, pada bulan Nopember 2011 di Jakarta. 
responden menyatakan tidak bersedia untuk merusak gereja tersebut. Tetapi sejumlah $40 \%$ bersedia merusak gereja yang tidak memiliki izin pendirian. Mengenai potensi toleransi juga terlihat pada pandangan Rohis terhadap pendirian tempat ibadah. Data yang ada menunjukkan bahwa sebanyak 63\% Rohis setuju pendirian rumah ibadah kelompok agama lain di dirikan dilingkungan rumah tempat tinggal. Sedangkan $37 \%$ Rohis tidak setuju adanya pendirian gereja di lingkungan tempat tinggalnya.

Meskipun di lihat dari prosentase tingkat potensi toleransi para siswa relatif tinggi, tentu masih belum menunjukkan hasil pendidikan agama Islam yang optimal. Karena data di atas juga menunjukkan tingkat potensi intoleransi para pengurus Rohis SMA/SMK masih berkisar antara $10 \%$ sd $37 \%$, tergantung pada aspek apa mereka harus bersikap untuk bertoleransi.

Tentu, potensi sikap intoleransi keagamaan yang masih berkembang di lingkungan sekolah perlu di cegah atau dikurangi dengan mengajarkan nilai-nilai multikultura ${ }^{37}$ yang selaras dengan ajaran agama yang memberikan rahmat bagi seluruh alam (rahmatan lilalamiin), ${ }^{38}$ dan nilai-nilai yang terkandung dalam Pancasila, Undang-Undang Dasar 1945 dan Undang-Undang Sistem Pendidikan Nasional ${ }^{39}$ Berbagai upaya untuk mencegah berkembangnya sikap dan prilaku intoleransi di sekolah telah banyak dilakukan namun hasilnya memang belum optimal. Indikasinya masih sering muncul konflik keagamaan antar kelompok

${ }^{37}$ Imam Tholkhah (ed). 2009. Pengembangan Pendidikan Agama Islam Berwawasan Multikultural, SMA/ SMK, Jakarta, Direktorat Pendidikan Agama Islam pada Sekolah.

${ }^{38}$ Imam Tholkhah (ed), 2010. Islam Rahmatan Lil 'alamiin - Buku Rujukan Guru PAI Sekolah Dasar, Sekolah Menengah Pertama, Sekolah Menengah Atas, Sekolah Menengah Kejuruan, Jakarta, Direktorat Pendidikan Agama Islam Pada Sekolah, Direktorat Jenderal Pendidikan Islam, Kementerian Agama, Tahun 2010.

${ }^{39}$ Marwan Sarijo (Penyunting) , Mereka Bicara Pendidikan Islam - Sebuah Bunga Rampai, Jakarta, PT Raja Grafindo Persada, Tahun 2009, h. 110 -129. Ahmad Barizi, dkk. Membuka Jendela Pendidikan - Mengurai Akar Tradisu dan Integrasi Keilmuan Pendidikan Islam, Jakarta, PT Grafindo Persada, tahun 2004, 171 - 182 umat berbeda agama dan interen umat beragama dalam masyarakat Indonesia. ${ }^{40}$

Salah satu upaya yang cukup strategis untuk mencegah berkembangnya sikap dan prilaku intoleransi ini adalah pengembangan budaya toleransi melalui pendidikan pada sekolah. ${ }^{41}$ Fungsi pendidikan, khususnya pendidikan agama di sekolah adalah untuk membentuk manusia Indonesia yang beriman dan bertaqwa kepada Tuhan Yang Maha Esa serta berahlak mulia dan mampu menjaga kedamaian hubungan inter dan antar umat beragama. ${ }^{42}$ Relevansi pengembangan budaya toleransi melalui pendidikan agama pada sekolah adalah: Pertama, dari segi yuridis ia merupakan tuntutan undang-undang nomor 20 tahun 2003 tentang Sistem Pendidikan Nasional, dan Peraturan Pemerintah no 55 tahu 2007, tentang penyelenggaraan Pendidikan Agama di Sekolah. Kedua, dari sudut sosiologis, kelompok anak-anak usia sekolah adalah pewaris dan kader-kader pemimpin dan tokoh masyarakat dan bangsa mendatang yang perlu mendapat bekal untuk memahami nilai-nilai toleransi dalam kehidupan bermasyarakat sebagai bagian dari bangsa Indonesia yang multikultural..$^{43}$ Ketiga, dari segi psykhologis, masa usia anak sekolah merupakan waktu yang tepat untuk penanaman nilai-nilai karakter bangsa, karena masa anak-anak usia sekolah merupakan masa yang sangat rentan untuk menerima berbagai pengaruh nilai-nilai yang negatif dari lingkungan sosialnya. Karena itu sejak masa kanak-kanak perlu memperoleh benteng yang kuat dengan nilai positif dalam kehidupan bermasyarakat.

${ }^{40}$ Tim Peneliti Balai Litbang Agama Jakarta. 2011. Kasus-KasusAktual Kehidupan Keagamaan - Studi Pencegahan Dini Konflik Umat Beragama. Jakarta: Balai Litbang Agama Jakarta.

${ }^{41}$ M.Ainul Yakin. 2005. Pendidikan Multikultural -Cross-Cultural Understanding untuk demokrasi dan Keadilan. Jakarta: Pilar Media. h. 61

${ }^{42}$ Peraturan Pemerintah Republik Indonesia Nomor 55 Tahun 2007 Tentang Pendidikan Agama dan Pendidikan Keagamaan, Bab II, Pasal 2, Jakarta, Direktorat Pendidikan Agama Islam pada Sekolah, Kementerian Agama.

${ }^{43}$ Imam Tholkhah. 2008. Manusia Agama dan Perdamaian, Jakarta, Al Ghazali, h. $152-172$ 


\section{HASIL DAN PEMBAHASAN Profil Siswa}

Di lihat dari sisi minat terhadap pendidikan agama, profil siswa menunjukkan bahwa mayoritas (92.00\%) siswa di sekolah dan Madrasah menyukai pendidikan agama. Data ini dapat bermakna bahwa lembaga sekolah dan madrasah beserta guru pendidikan agama relatif berhasil dalam menarik simpati para siswa dalam belajar agama, meskipun bukan faktor tunggal. Faktor lain yang ikut mendorong minat para siswa terhadap pendidikan agama adalah karena adanya kepedulian orang tua siswa terhadap pendidikan agama. Dari data yang diperoleh, mayoritas siswa (90.00\%) memperoleh perhatian pendidikan agama dari orangtuanya. Data ini memiliki makna bahwa hingga saat ini orang tua memiliki kepedulian yang tinggi terhadap pendidikan agama anakanaknya. Kondisi ini tentunya sangat mendukung pendidikan agama yang ada di sekolah, dan mempengaruhi minat siswa untuk belajar agama.

Namun tingginya minat siswa terhadap pendidikan agama dan tingginya kepedulian orang tua terhadap pendidikan agama di rumah tidak secara otomatis melahirkan siswasiswa yang taat menjalankan petunjuk agama, khususnya amalan ibadah ritual. Data yang ada, para siswa yang mengakui taat beribadah jumlahnya lebih kecil di banding dengan para siswa yang menyatakan memiliki minat belajar agama dan orang tuanya sangat peduli terhadap pendidikan agama siswa, meskipun data jumlah siswa yang taat beribadah masih masuk dalam kategori cukup tinggi. Secara umum para siswa yang menyatakan diri taat beribadah, seperti sering/selalu berdoa sebesar $82 \%$, mengaku sering/selalu menjalankan sholat wajib/kebaktian sebesar 78\%, mengaku membaca kitab suci sebesar $62 \%$. Khusus untuk siswa muslim yang mengaku sering sholat berjamaah sebesar $66 \%$, yamg mengaku melakukan sholat sunnah 35\% dan yang mengaku melakukan puasa sunnah sebesar $30 \%$.

Meskipun minat siswa dan kepedulian orang tua terhadap pendidikan agama tergo- long tinggi, dan pengamalan ibadah ritual para siswa relatif tinggi, para guru tetap dituntut untuk terus berusaha meningkatkan mutu pendidikan agama. Karena, dari segi minat belajar agama terdapat sebesar 7.0\% siswa yang tidak menyukai pendidikan agama. Idealnya seluruh siswa sebaiknya memiliki minat belajar agama. Banyak sebab mengapa sebagian siswa tersebut tidak menyukai pendidikan agama. Diantara alasan utamanya adalah bahwa menurut mereka "materi pendidikan agama sangat sulit dipahami (32\%), cara mengajar guru agama membosankan (21\%), dan guru mengajar terlalu banyak pendekatan hafalan (18\%). Data tersebut bisa dipahami karena sebagian guru agama di sekolah memang belum sepenuhnya memiliki kompetensi sebagai guru agama yang memadai, dan juga belum memenuhi standar kualifikasi pendidikan yang diharuskan oleh Undang-Undang. Oleh karena itu guru pendidikan agama dan satuan pendidikan sekolah masih dihadapkan pada tantangan untuk meningkatkan kualitas pembelajaran pendidikan agama, agar setiap siswa makin merasa mudah mempelajari dan menyukai materi pendidikan agama.

Namun, kurangnya minat siswa terhadap pendidikan agama bukan hanya disebabkan oleh kualitas guru, tetapi juga karena faktor keluarga. Data yang ada, memperlihatkan bahwa terdapat sekitar $10 \%$ siswa menyatakan tidak memperoleh perhatian atau kepedulian pendidikan agama dari orang tuanya. Kondisi ini menyumbang belum maksimalnya tingkat ketaan ibadah para siswa di banding dengan minat siswa mempelajari pendidikan agama. Atas dasar ini, maka guru pendidikan agama dituntut untuk memberikan perhatian khusus kepada para siswa yang kurang memperoleh perhatian dari orang tuanya. Karena, jika mereka yang tidak memperoleh perhatian pendidikan agama juga tidak memperoleh perhatian khusus dari guru pendidikan agama, para siswa tersebut akan menjadi para siswa yang paling rentan oleh pengaruh pendidikan agama dari luar sekolah yang mungkin saja kurang sesuai dengan wawasan kebangsaan. 
Di lihat dari segi keaktifan siswa dalam mangikuti kegiatan extra kurikuler dari organisasi keagamaan, jumlahnya relatif kecil. Untuk siswa muslim, mereka yang mengaku ikut aktif pada kegiatan ROHIS hanya berkisar $22 \%$, sedangkan para siswa Kristen yang mengaku aktif mengikuti kegiatan ROHKRIS jumlahnya lebih besar, yakni $45 \%$. Data ini bermakna bahwa organisasi siswa keagamaan masih fungsional untuk wadah pembinaan pendidikan agama, meskipun dalam data tersebut jumlah siswa yang aktif relatif kecil. Dalam beberapa wawancara dengan para guru agama, para siswa yang mengikuti aktivitas organisasi keagamaan umumnya termasuk para siswa dalam kategori pintar, cerdas, religius dan berahlak baik. Meski data siswa muslim yang aktif dalam kegiatan Rohis relatif kecil, mereka memiliki pengaruh tertentu dalam upaya meningkatkan ahlak, mencegah perbuatan a moral dan menjauhi Narkoba. ${ }^{44}$ Hanya saja menurut para pembina Rohis, akhir-akhir ini minat siswa terhadap Rohis dirasakan makin menurun. Sebagian dari para siswa tidak bersedia mengikuti kegiatan Rohis karena adanya banyak berita yang menyudutkan Rohis, yaitu Rohis telah diwarnai oleh kelompok gerakan faham radikal Islam. ${ }^{45}$

Di tinjau dari segi keterlibatan siswa dalam organisasi keagamaan di luar sekolah, sebagian siswa mengaku ikut serta dalam organisasi keagamaan dalam masyarakat, baik yang sifatnya

${ }^{44}$ Farid Wajidi. 2013. "Kaum Muda dan Pluralisme Kewarganegaraan" -Makalah Seminar Membangun Budaya Damai dan Toleran di Kampus. Jakarta: Puslitbang Pendidikan Agama dan Keagamaan.

${ }^{45}$ Sejalan dengan temuan ini, penelitian yang dilakukan oleh Farid Wajdi, Salim HS, Hairus, dan Wahyu Kustiningsih tahun 2009 dan 2010 menyatakan bahwa: meskipun Rohis berada di bawah pengawasan sekolah, akan tetapi hubungan dan jaringan politik mereka dengan gerakan-gerakan Islam di luar sekolah, terutama yang berbasis di perguruian tinggi, membuat agenda dan tujuan mereka lebih politis-ideologis melampaui tujuan kelembagaan ekskul yang digariskan oleh sekolah (Kailani 2009, 2010, Wajdi 2011). Tesis Sastro al Ngatawi juga menyebutkan: terdapat kecenderungan bahwa anak usia sekolah menjadi basis prekrutan anggota kelompok radikal (Tim Peneliti Puslitbang Penda, 2011. Penelitian Paham Keagamaan .Jakarta: Puslitbang Pendidikan Agama dan Keagamaan. moderat atau radikal. Namun para siswa yang ikut serta dalam kegiatan organisasi keagamaan tersebut jumlahnya relatif kecil. Organisasi keagamaan yang paling tinggi diikuti para siswa adalah Nahdatul Ulama (NU), dengan jumlah siswa yang terlibat sebesar $19.04 \%$, kemudian Muhammadiyah, dengan jumlah siswa 05,70\%. NU dan Muhammadiyah adalah organisasi keagamaan Islam terbesar di Indonesia, dikenal sebagai organisasi keagamaan yang moderat, dan memiliki pengaruh besar dalam masyarakat dan lembaga - lembaga negara. Di Indonesia, banyak tokoh masyarakat dan tokoh nasional yang memiliki latarbelakang NU dan Muhammadiyah. Pada masa lalu, organisasi NU memiliki onderbow Ikatan Pelajar Nahdlatul Ulama (IPNU) dan Muhammadiyah memiliki onderbow Ikatan Pelajar Muhammadiyah, yang keduanya di masa lalu memiliki basis kegiatan di sekolah.

Selain itu, terdapat juga para siswa sekolah yang ikut serta dalam kegiatan organisasi keagamaan yang sifatnya radikal atau exclusif. Bentuk keterlibatan para siswa tersebut adalah dengan mengikuti kegiatan-kegiatan pengajian dari kelompok organisasi keagamaan tersebut. Biasanya kegiatan pengajian tersebut diadakan di lingkungan masjid atau tempattempat terbuka lainnya. Meskipun jumlahnya relatif sangat kecil, para siswa yang terlibat dalam organisasi keagamaan tersebut dinilai memiliki militansi yang tinggi dan fanatisme keagamaan yang kuat. Organisasi keagamaan tersebut adalah Jamaah Tabligh, diikuti oleh 4.4\% siswa, kemudian Front Pembela Islam (2,9\%), Jamaah Anshorut Tauhid (1,9\%), Hizbuttahrir Indonesia (1,6\%), Brigade Hizbullah $(1,3 \%)$, Majelis Mujahidin Indonesia (1,2\%), dan Front Hizbullah, (0,8\%).

Meskipun para siswa yang terlibat dalam organisasi keagamaan relatif kecil, tingkat ketaatan beribadah siswa diukur melalui intensitas menjalankan ibadah ritual wajib, seperti shalat lima waktu, puasa atau kebaktian relatif besar. Dalam kaitan ini para siswa yang menyatakan selalu menjalankan ibadah ritual wajib masuk dalam kategori taat, siswa yang sering melakukan ibadah wajib masuk kategori relatif 
taat. Semakin tinggi frekuensi melakukan ibadah ritual wajib semakin taat. Dari data yang diperoleh, sebesar $78.00 \%$ siswa pada semua agama mengaku selalu dan sering menjalankan ibadah wajib sholat lima waktu/kebaktian. Sedangkan mereka yang mengaku jarang atau tidak pernah melakukan ibadah wajib sebesar $20.00 \%$. Gambaran tingkat ketaatan secara lebih rinci sebagaimana tabel berikut

Tabel 1

Tingkat Ketaatan Ibadah Siswa $(\mathrm{N}=804)$

\begin{tabular}{|c|l|r|r|r|r|r|}
\hline No & Jenis Ibadah & $\begin{array}{c}\text { Selalu } \\
(\%)\end{array}$ & $\begin{array}{c}\text { Sering } \\
(\%)\end{array}$ & $\begin{array}{c}\text { Jarang } \\
(\%)\end{array}$ & $\begin{array}{c}\text { Tidak } \\
\text { Pernah } \\
(\%)\end{array}$ & $\begin{array}{c}\text { Tidak } \\
\text { Jawab } \\
(\%)\end{array}$ \\
\hline 1 & $\begin{array}{l}\text { Sholat } \\
\text { limawaktu/ } \\
\text { Kebaktian/ } \\
\text { Misa }\end{array}$ & 49.4 & 28.6 & 21.4 & 1 & 0.4 \\
\hline 2 & $\begin{array}{l}\text { Berdoa dalam } \\
\text { kegiatan } \\
\text { sehari-hari }\end{array}$ & 41.2 & 40.8 & 16.4 & 0.1 & 1.4 \\
\hline 3 & $\begin{array}{l}\text { Membaca } \\
\text { Kitab Suci }\end{array}$ & 27.3 & 35.6 & 34.5 & 1.1 & 1.5 \\
\hline 4 & $\begin{array}{l}\text { Mengikuti } \\
\text { kajian/ } \\
\text { Pengajian }\end{array}$ & 17.2 & 31.6 & 45.5 & 4.1 & 1.6 \\
\hline
\end{tabular}

Sumber: Data Primer

Tabel 1 dapat dimaknai bahwa hasil pendidikan agama di sekolah masih relatif rendah, dan guru agama belum berhasil secara maksimal mendorong siswa untuk taat beribadah ritual, berdoa, membaca kitab suci dan mengikuti pengajian. Hal ini terlihat dari adanya data sejumlah siswa yang menyatakan: 1) jarang dan tidak menjalankan sholat lima waktu/kebaktian sebesar 22,4\%; 2) jarang dan tidak berdoa $16,5 \%$; 3) jarang dan tidak membaca kitab suci $35,6 \%$; 3 ) jarang dan tidak pernah mengikuti kajian/pengajian 49,6\%.

\section{Potensi Intoleransi Keagamaan Siswa}

Dalam penelitian ini potensi intoleransi keagamaan siswa diukur melalui jawaban-jawaban terhadap 3 bentuk pernyataan tertentu yang telah disusun oleh tim peneliti Puslitbang Pendidikan Agama, sebelum turun ke lapangan. Pertama, para siswa di minta menjawab pertanyaan yang terkait dengan berbagai jenis tindakan warga, dengan memilih salah satu jawaban yang sesuai pada kolom: tidak setuju, kurang setuju, setuju, sangat setuju. Uraian berikut adalah gambaran pertanyaan dan jawaban para siswa yang terkait dengan berbagai tindakan warga, yang dibuat dalam bentuk tabel.

Tabel 2

\section{Gambaran Potensi Intoleransi Keagamaan} Siswa Sekolah dan Madrasah

$$
(\mathrm{N}=\mathbf{8 0 4})
$$

\begin{tabular}{|c|c|c|c|c|c|c|c|}
\hline \multirow[t]{2}{*}{ No } & \multirow{2}{*}{$\begin{array}{l}\text { Jenis Pernyataan/aksi } \\
\text { yang ditanyakan pada } \\
\text { responden }\end{array}$} & \multicolumn{2}{|c|}{$\begin{array}{c}\text { Persetujuan } \\
\text { thd warga } \\
\text { yang melaku- } \\
\text { kan aksi } \\
\end{array}$} & \multicolumn{2}{|c|}{$\begin{array}{l}\text { Bersedia diajak } \\
\qquad \text { aksi }\end{array}$} & \multicolumn{2}{|c|}{$\begin{array}{l}\text { Pengalaman } \\
\text { melakukan } \\
\text { aksi }\end{array}$} \\
\hline & & $\begin{array}{l}\text { Setuju } \\
(\%)\end{array}$ & $\begin{array}{c}\text { Tidak } \\
\text { setuju } \\
(\%)\end{array}$ & \begin{tabular}{|c|} 
Bersedia \\
$(\%)$
\end{tabular} & $\begin{array}{l}\text { Tidk } \\
\text { sedia } \\
(\%)\end{array}$ & $\begin{array}{l}\text { Pernah } \\
(\%)\end{array}$ & $\begin{array}{l}\text { Tidak } \\
(\%)\end{array}$ \\
\hline 1 & \begin{tabular}{|l|} 
Menyegel/merusak \\
tempat hiburan (bar/ \\
kafe/tempat perjudian) \\
\end{tabular} & 76,70 & 22.8 & 42.4 & 57.1 & 0.2 & 99.0 \\
\hline 2 & $\begin{array}{l}\text { Menangkap/mengha- } \\
\text { kimi pasangan bukan } \\
\text { suami istri }\end{array}$ & 68,4 & 31.6 & 35.0 & 63.4 & 1 & 97.6 \\
\hline 3 & $\begin{array}{l}\text { Menentang kegiatan } \\
\text { keagamaan yang } \\
\text { dilakukan oleh } \\
\text { aliran keagamaan } \\
\text { lain yang dianggap } \\
\text { menyimpang }\end{array}$ & 59,9 & 39.3 & 36.3 & 63.5 & 0.6 & 98.4 \\
\hline 4 & \begin{tabular}{|l} 
Menolak pemeluk \\
agama lain menjadi \\
presiden
\end{tabular} & 36,9 & 62.5 & 21.2 & 78.4 & 0.3 & 98.7 \\
\hline 5 & \begin{tabular}{|l|} 
Merusak rumah/ \\
fasilitas milik anggota \\
aliran keagamaan \\
yang dianggap \\
menyimpang
\end{tabular} & 25,6 & 73.5 & 15.1 & 84.4 & 0.1 & 98.7 \\
\hline 6 & \begin{tabular}{|l|} 
Menolak pemba- \\
ngunan rumah ibadah \\
agama lain
\end{tabular} & 25.4 & 74.4 & 14.6 & 84.8 & 0.2 & 98.7 \\
\hline 7 & $\begin{array}{l}\text { Menolak guru karena } \\
\text { agamanya berbeda }\end{array}$ & 21,9 & 77.6 & 14.0 & 85.3 & 0.4 & 98.2 \\
\hline 8 & \begin{tabular}{|l|} 
Menolak pelaksanaan \\
ibadah pemeluk \\
agama lain
\end{tabular} & 17.2 & 82.5 & 7.6 & 92.3 & 0,2 & 99.3 \\
\hline & Rata-Rata & 41.45 & 58.03 & 23.9 & 76.6 & 0.25 & 98.58 \\
\hline
\end{tabular}

Sumber: Data Primer

Tabel di atas menggambarkan bahwa potensi intoleransi keagamaan siswa bersifat dinamis, tergantung pada kasus atau variabel mana para siswa tersebut di hadapkan. Di satu sisi, para siswa yang dihadapkan pada halhal tertentu potensi intoleransi keagamaan mereka dapat di pandang rendah atau sangat rendah, tetapi dihadapkan pada hal-hal yang lain dapat dipandang tinggi atau sangat tinggi. Berdasarkan tabel di atas, uraian berikut adalah gambaran tingkat potensi intoleransi para siswa yang berbeda-beada.

Fenomena tingkat potensi intoleransi keagamaan siswa tertinggi adalah terlihat pada respon siswa pada variabel persetujuan terha- 
dap tindakan masyarakat yang menyegel atau merusak tempat-tempat hiburan. Dalam Tabel 1 di atas terlihat bahwa sejumlah $76,70 \%$ siswa yang menjadi sampel penelitian menyatakan setuju terhadap tindakan sekelompok masyarakat yang menyegel atau merusak tempat-tempat hiburan, yang di dalamnya terdapat tempat perjudian. Dari perspektif variabel persetujuan ini, mayoritas siswa di daerah penelitian dapat dimaknai mengandung potensi intoleransi keagamaan yang sangat tinggi. ${ }^{46}$

Dalam studi ini, tidak ada data yang menjelaskan mengapa tingkat potensi intoleransi pada variabel persetujuan terhadap tindakan masyarakat yang menyegel atau merusak tempat hiburan tersebut paling tinggi. Menurut hemat penulis, tingginya persetujuan para siswa terhadap tindakan masyarakat yang menyegel atau merusak tersebut, bukan karena mereka tidak menyukai tempat hiburan, tetapi karena fungsi tempat hiburan tersebut sudah digunakan sebagai tempat maksiayat, yakni tempat berjudi. Secara kognitif para siswa telah memperoleh pelajaran di sekolah, bahwa ajaran agama Islam melarang umatnya untuk berjudi. Mereka memahami bahwa dari aspek sosial dan ekonomi, perbuatan judi lebih banyak madhorotnya dari pada keuntungannya. Dari sudut common sense, judi juga dapat menjadi sumber malapetaka keluarga dan masyarakat. Karena dampak dari judi, bagi mereka yang kecanduan dan kalah, mereka dapat berbuat nekat melakukan pencuriam, perampokan dan kriminal yang lain. Karenanya tidak mengherankan kalau para siswa akan menyetujui tindakan radikal masyarakat yang melakukan tindakan menyegel atau merusak tempat hiburan yang menjadi tempat bejudi tersebut.

Namun tidak seluruh siswa yang menyetujui tindakan warga yang merusak tersebut

${ }^{46}$ Makna mengandung potensi intoleransi dalam indikator ini karena tindakan menyegel, menutup atau merusak tempat hiburan yang menjadi tempat maksiyat bukan kewenangan kelompok atau masyarakat pada umumnya, tetapi kewenangan para penegak hukum. Kelompok masyarakat tidak memiliki kewenangan main hakim sendiri. bersedia untuk diajak melakukan tindakan radikal semacam itu. Dari seluruh responden, terdapat $42,4 \%$ siswa yang menyatakan bersedia diajak untuk melakukan aksi radikal menutup dan merusak tempat hiburan yang sekaligus juga sebagai tempat berjudi. Menurut hemat penulis mereka ini dapat dikategorikan sebagai siswa yang berpotensi radikal, yang tentu saja sangat rentan dari pengaruh gerakan-gerakan faham keagamaan yang radikal. Dari jumlah tersebut para siswa yang mengaku pernah melakukan aksi radikal semacam itu terdapat sekitar $0.2 \%$ dari total jumlah responden.

Dari perspektif variable ini, maka dapat dikatakan bahwa para siswa yang nampak nyata sebagai para siswa yang toleran adalah hanya sekitar $23.00 \%$. Mereka adalah para siswa yang tidak sependapat kalau masyarakat melakukan tindakan radikal menyegel atau merusak tempat hiburan yang menjadi tempat berjudi. Hal ini, bukan berarti bahwa para siswa setuju dengan tempat hiburan sebagai tempat judi, tetapi mungkin karena mereka memahami bahwa dari sisi hukum positif, para siswa mengetahui bahwa tindakan radikal semacam itu dinilai sebagai tindakan yang melanggar hukum, karena mereka main hakim sendiri. Mereka mungkin memahami bahwa tindakan untuk menyegel, menutup atau membongkar tempat semacam itu merupakan kewenangan aparat penegak hukum.

Fenomena tingkat potensi intoleransi keagamaan siswa tertinggi kedua nampak pada respon siswa pada variabel persetujuan terhadap tindakan warga yang menangkap dan menghakimi pasangan bukan suami isteri. Dalam hal ini, sebesar 68,4\% siswa yang menjadi sampel penelitian menyatakan persetujuan terhadap tindakan menangkap dan menghakimi pasangan suami isteri. Tingginya potensi intoleransi dalam hal ini dapat dipahami karena, dari sudut normatif dan ajaran agama yang diperoleh para siswa di sekolah atau masyarakat, bahwa yang dimaksud pasangan yang sah dalam keluarga adalah pasangan suami isteri. Pasangan yang bukan suami isteri dapat dipandang melanggar ajaran agama. Dalam tradisi masyarakat tradisional (umumnya di pedesaan) apabila 
ditemui pasangan bukan suami isteri tinggal dalam sebuah tempat tertentu, pasangan tersebut akan ditangkap dan di adili secara adat, seperti dipermalukan dengan di arak di depan umum.

Namun dari potensi intoleran tersebut, tidak seluruhnya bersedia apabila diajak untuk melakukan aksi radikal sebagaimana dilakukan warga yang menangkap dan menghakimi pasangan yang bukan suami isteri. Mereka yang bersedia melakukan tindakan radikal tersebut berjumlah $35.0 \%$, lebih kecil sedikit dibanding dengan kesediaan melakukan tindakan radikal menutup dan merusak tempat hiburan yang menjadi tempat judi. Dari potensi intoleransi /radikal ini yang berpengalaman melakukan tindakan radikal semacam itu berjumlah $1.0 \%$.

Dari perspektif variabel tindakan masyarakat menangkap atau menghakimi pasangan bukan suami isteri, yang tidak setuju sebesar $31,6 \%$. Data ini dapat memberi makna bahwa hanya sebagian kecil dari para siswa yang nampak toleran dan memahami bahwa menangkap atau menghakimi pasangan bukan suami isteri bukan kewenangan atau kewajiban masyarakat umum, tetapi kewajiban para penegak hukum.

Fenomena tingkat potensi intoleransi keagamaan siswa tertinggi ketiga nampak pada respon siswa pada variabel persetujuan terhadap tindakan warga yang menentang kegiatan keagamaan yang dilakukan oleh aliran yang dianggap menyimpang. Untuk variabel ini para siswa yang menyetujui tindakan warga yang menentang terhadap kegiatan keagamaan dari aliran yang dianggap menyimpang sebesar 59,9\%. Tingginya penentangan terhadap aliran keagamaan yang menyimpang ini kemungkinan dapat disebabkan karena beberapa faktor. Pertama, faktor anggapan penodaan pada agama yang dianut. Dalam beberapa kasus, seperti penentangan kelompok Islam tertentu kepada aliran Ahmadiyah atau Syiah, karena kedua aliran tersebut dianggap oleh sebagian kelompok Islam sebagai aliran agama yang menyesatkan dan menodai agama yang diyakini oleh mayoritas umat Islam Indonesia. Kedua, faktor sosial; Komunitas aliran yang menyimpang sering di pandang oleh sebagian masyarakat sebagi kelompok masyarakat yang exclusive, kurang mampu membaur dengan masyarakat luas dan sistem peribadatan, termasuk tempat ibadah alairan tersebut terkesan tidak terbuka untuk umum. Ketiga, faktor ekonom. Kelompok aliran yang dipandang sesat, dalam beberapa kasus seringkali secara ekonomi lebih baik di banding masyarakat umum sekitarnya. Adanya gap ekonomi antara kelompok aliran yang dipandang menyimpang dengan masyarakat umum di sekitarnya dapat melahirkan kecemburuan sosial, sehingga masyarakat sekitar lebih mudah diprovokasi melakukan tindakan penolakan terhadap aliran tersebut. Keempat, faktor politik. Adanya kepentingan individu atau kelompok tertentu, faham keagamaan yang dinilai oleh masyarakat sebagai aliran sesat dapat dijadikan sasaran konflik sosial untuk mendapatkan simpati atau dukungan masyarakat luas.

Namun sebagaimana dijelaskan pada bagian terdahulu, tidak semua yang menyetujui tindakan warga yang bersifat radikal, juga bersedia bertindak radikal. Dari data yang ada jumlah para siswa yang bersedia melakukan tindakan radikal dengan melakukan aksi menentang kelompok aliran agama yang dinilai menyimpang sebesar $36,3 \%$. Potensi radikal pada aspek ini sedikit lebih besar sedikit di banding dengan potensi radikal siswa menghadapi pasangan yang bukan suami isteri, namun masih lebih kecil dibanding dengan potensi radikal menghadapi tempat hiburan yang menjadi tempat judi. Dari jumlah ini yang sudah berpengalaman melakukan tindakan radikal menentang kelompok aliran yang dinilai menyimpang berjumlah $0.6 \%$.

Potensi intoleransi keagamaan siswa urutan keempat adalah nampak pada persetujuan para siswa terhadap variabel persetujuan untuk menolak pemeluk agama lain menjadi presiden. Jumlah para siswa yang setuju terhadap tindakan warga yang menolak pemeluk agama lain menjadi presiden, tergolong minoritas, jumlahnya sebesar $36,9 \%$. Pandangan sejumlah siswa semacam ini dapat dipahami karena beberapa alasan: Pertama, adanya ajar- 
an keagamaan yang mendorong masyarakat Islam untuk memilih pemimpin yang seagama di dalam masyarakat. Ajaran semacam ini tidak masuk dalam standar isi atau kurikulum pendidikan agama di sekolah atau madrasah. Tetapi, para siswa kemungkinan besar mendapatkan pengetahuan melalui kampanye politik dan ceramah-ceramah langsung dalam masyarakat atau mendapatkan pengetahuan secara tidak langsung melalui pembicaraan informal dalam komunitasnya. Kedua, dari aspek sosial, terdapat kekhawatiran kelompok masyarakat beragama (sebagian termasuk siswa) terhadap presiden yang berbeda agama akan mementingkan agama yang di anut oleh presiden. Dalam hal ini penganut agama yang berbeda dengan agama presiden khawatir akan di diskriminasikan oleh presiden. Ketiga, secara psikologis mereka mungkin lebih nyaman kalau presiden itu seagama.

Tabel di atas juga menunjukkan tidak seluruh siswa yang setuju tindakan warga menolak presiden yang tidak seagama juga bersedia melakukan aksi penolakan di lapangan. Dari jumlah tersubut hanya sekitar $21,1 \%$ yang bersedia melakukan aksi penolakan. Selebihnya, mayoritas siswa sebesar78.4\% dari jumlah responden yang berpotensi toleran, dalam arti mereka tidak bersedia bila di ajak untuk melakukan tindakan penolakan terhadap presiden yang berbeda agama. Namun dari data tersebut, para siswa yang nampak benar-benar toleran terhadap keagamaan presiden lebih kecil sedikit, yakni $62.5 \%$ dari jumlah responden. Karena itu tidak mengherankan, jika isu agama di kaitkan dengan pimpinan daerah seperti pemilihan Kepala Daerah DKI Jakarta, tidak banyak berpengaruh pada mayoritas pemilih.

Fenomena potensi intoleransi keagamaan siswa urutan ke lima, nampak pada variabel persetujuan siswa terhadap tindakan warga yang merusak rumah/ fasilitas milik anggota aliran keagamaan yang dianggap menyimpang. Jumlah para siswa yang setuju terhadap tindakan warga yang merusak rumah/fasilitas milik anggota aliran keagamaan lain yang menyimpang, relatif minoritas, yakni sebesar
$25,6 \%$. Sedangkan mayoritas siswa $(74,4 \%)$ telah memiliki potensi toleransi terhadap penganut aliran agama yang berbeda. Mereka tidak sependapat kalau masyarakat merusak rumah/fasilitas milik anggota aliran keagamaan lain yang menyimpang. Data inidapat dinilai bahwa mayoritas siswa sekolah dan madrasah telah memiliki wawasan multikultural, dan memahami aturan bahwa merusak fasilitas yang bukan miliknya melanggar hukum agama maupun hukum negara.

Dari sejumlah siswa yang relatif minoritas tersebut tidak seluruhnya bersedia untuk diajak melakukan aksi anarkis untuk merusak rumah/fasilitas milik anggota aliran keagamaan lain yang menyimpang. Jumlah siswa yang bersedia diajak melakukan tindakan anarkis tersebut sebesar $15.1 \%$. Kelompok siswa inilah yang dapat dipandang potensial menjadi kelompok radikal yang anarkis. Dari jumlah ini para siswa yang menyatakan sudah berpengalaman melakukan tindakan anarkis semacam itu sebesar $01 \%$. Adanya potensi radikal anarkis pada seklompok minoritas siswa tersebut kemungkinan di latarbelakangi adanya fanatisme keagamaan siswa yang masih tinggi, adanya pengaruh kelompok keagamaan radikal terhadap siswa tersebut dan belum fahamnya mereka terhadap peraturan hukum positif negara kesatuan Indonesia, serta kurangnya wawasan multikultural dan wawasan keagamaan yang rahmatan lil alamin para siswa tersebut.

Fenomena tingkat potensi intoleransi keagamaan para siswa peringkat ke enam, nampak pada variabel persetujuan siswa terhadap tindakan warga yang menolak pembangunan rumah ibadah agama lain. Jumlah para siswa yang setuju pada tindakan warga yang menolak pembangunan rumah ibadah lain, tergolong minoritas, yakni sebesar $25,4 \%$. Sedangkan mayoritas siswa, sebesar $74,6 \%$ dari responden memiliki potensi toleransi yang kuat terhadap pembangunan rumah ibadah agama lain. Adanya kelompok minoritas siswa yang berpotensi intoleran terhadap pembangunan tempat ibadah agama lain, menunjukkan mereka belum memiliki wawasan multikultural, dan masih memiliki fanatisme keagamaan yang kuat. 
Namun sebagaimana pada aspek sebelumnya, tidak seluruh kelompok minoritas siswa tersebut bersedia melakukan aksi lapangan menolak pembangunan rumah ibadah agama lain. Para siswa yang bersedia melakukan tindakan menolak pembangunan tempat ibadah tersebut sebesar $14.6 \%$, atau lebih kecil sedikit atau relatif sama dengan jumlah kelompok minoritas siswa yang bersedia melakukan tindakan anarkis merusak rumah/fasilitas milik penganut aliran agama yang menyimpang sebesar $15.2 \%$. Dari jumlah tersebut para siswa yang berpengalaman melakukan aksi penolakan terhadap pembangunan tempat ibadah agama lain sebesar $0.2 \%$. Para siswa ini kemungkinan besar memang belum memiliki wawasan multikultural Indosesia dan memahami makna berbagai perundangan yang menghargai perbedaan agama.

Fenomena tingkat potensi intoleransi keagamaan para siswa urutan ketujuh nampak pada respon siswa terhadap variabel tindakan warga yang menolak guru yang berbeda agama dengan siswa. Dalam hal ini jumlah siswa yang setuju pada tindakan warga yang menolak guru karena alasan agamanya berbeda, masuk dalam kategori minoritas, dengan jumlah sebesar $21,9 \%$. Mereka ini masuk dalam kategori kelompok minoritas yang berpotensi intoleran dalam hal agama. Sedangkan kelompok mayoritas siswa sekolah/madrasah sebesar $77,6 \%$ memiliki potensi toleransi keagamaan yang kuat. Tentu yang dimaksud guru di sini adalah guru yang bersifat umum, dan bukan spesifik guru agama. Sebab, kalau guru agama sudah menjadi ketentuan perundangan, yakni semua guru agama yang mengajar di sekolah harus memiliki agama yang sama dengan agama para peserta didiknya. Ketentuan ini sudah tercantum dalam Undang-Undang Nomor 20 Tahun 2003, Tentang Sistem Pendidikan Nasional, dalam Peraturan Pemerintah no 55 Tahun 2007, dan Peraturan Menteri Agama nomor 16 Tahun 2010, Tentang Pengelolaan Pendidikan Agama Di Sekolah.

Dari sejumlah kelompok minoritas siswa tersebut yang brpotensi radikal, dalam arti bersedia melakukan aksi penolakan terhadap guru yang berbeda agama jumlahnya lebih kecil, yakni sebesar 14.0\%. Dari jumlah ini, mereka yang berpengalaman menolak guru yang berbeda agama sebesar 04.0\%. Jumlah ini relatif sama dengan jumlah kelompok minoritas siswa yang berpotensi radikal anarkis dalam menghadapi kelompok aliran keagamaan yang menyimpang.

Fenomena tingkat potensi intoleransi keagamaan para siswa urutan kedelapan atau terkecil nampak pada respon siswa terhadap variabel tindakan warga yang menolak pelaksanaan ibadah pemeluk agama lain. Dalam kaitan ini, jumlah siswa yang setuju pada tindakan warga yang menolak pelaksanaan ibadah pemeluk agama lain berjumlah $\mathbf{1 7 , 2} \%$. Namun tidak seluruh siswa yang memiliki potensi intoleransi ini menyatakan bersedia jika ada yang mengajak untuk melakukan aksi penolakan terhadap pelaksanaan ibadah agama lain. Para siswa yang menyatakan bersedia di ajak melakukan aksi penolakan terhadap pelaksanaan ibadah agama lain sebesar 7,6\%, dan mereka yang pernah berpengalaman melakukan tindakan penolakan terhadap pelaksanaan ibadah agama lain sebesar $0,2 \%$. Jumlah inilah yang dapat dipandang sebagai potensi riil menjadi pengikut gerakan radikal keagamaan yang perlu memperoleh perhatian.

Namun di sisi lain tabel di atas juga menggambarkan bahwa mayoritas siswa $(82,5 \%)$ memiliki potensi toleransi keagamaan terhadap pelaksanaan ibadah pemeluk agama lain. Mayoritas siswa tidak sependapat dengan tindakan warga yang menolak pelaksanaan ibadah pemeluk agama lain. Bahkan, 92,3\% siswa tidak akan bersedia bila di ajak untuk melakukan tindakan penolakan terhadap pelaksanaan ibadah pemeluk agama lain. Dari sudut ini dapat dimaknai, bahwa mayoritas siswa telah memiliki wawasan multikultural dan telah memahami hak-hak setiap warga negara Indonesia untuk beribadah sesuai dengan agama dan kepercayaan yang dianutnya, sebagaimana tercantum dalam Undang-Undang Dasar 1945. 


\section{PENUTUP}

Pada bagian penutup ini penulis menekankan kembali beberapa catatan:

Pertama, dari sudut perkembangan pendidikan agama, hasil penelitian ini memperlihatkan bahwa minat dan perhatian para siswa di sekolah dan madrasah untuk mempelajari agama masih cukup tinggi. Potensi ini perlu mendapatkan respon yang lebih baik bagi para pengembang pendidikan agama di sekolah.

Kedua, dari aspek pemahaman keagamaan, pada umumnya para siswa memiliki pandangan keagamaan yang inklusif dan toleran. Hanya sebagian kecil dari para siswa yang memiliki pandangan keagamaan radikal-intoleran. Pandangan keagamaan intoleran ini tidak berasal dari pendidikan agama di sekolah, tetapi mereka peroleh melalui pergaulannya di luar sekolah. Meskipun dari segi prosentase jumlah mereka minoritas, tetapi kalau dibiarkan dapat semakin besar dan dalam waktu yang panjang akan menjadi potensi yang mengganggu persatuan dan kesatuan bangsa.

Ketiga, untuk mencegah berkembangnya paham keagamaan yang radikal intoleran pada kelompok siswa, diperlukan upaya-upaya pengembangan wawasan multikultural dan budaya toleransi keagamaan pada sekolah. Dalam kaitan ini peran kepala sekolah dan guru, khususnya guru agama harus mampu melakukan deteksi dini terhadap kemungkinan berkembangnya sikap radikal dengan melakukan pengawasan langsung atau tidak langsung, serta melakukan dialog-dialog dengan para siswa serta melakukan pembinaan pendidikan agama yang semakin intensif dan berkelanjutan.

\section{SUMBER BACAAN}

Affiyah. Neng Dara Gerakan Keislaman Pasca Orde Baru - Upaya Merambah Dimensi Baru Islam. Jakarta: Badan Litbang Agama dan Diklat Keagamaan.

Azra, Azyumardi. 2012. dkk. 2005 (eds) "Radikalisme Keagamaan dan Deradikalisasi:"
Peran Aparat Negara, Pemimnpin Agama dan Guru Untuk Kerukunan Umat Beragama. Makalah Seminar. Jakarta: Direktorat Pendidikan Islam

Bafadhal, Fadhal AR (ed), 2005. Pemuda dan Pergumulan Nilai pada Era Globa Jakarta: Badan Litbang Agama dan Diklat Keagamaan.

Barizi, Ahmad dan Imam Tholkhah. 2004. Membuka Jendela Pendidikan - Mengurai Akar Tradisu dan Integrasi Keilmuan Pendidikan Islam, Jakarta, PT Grafindo Persada.

Djamas, Nurhayati. 2005. Pengembangan Agama Berwawasan Multikultural. Jakarta: Puslitbang Pendidikan Agama dan Keagamaan.

Fanani dkk (eds). 2002. Gerakan Islam Klasik \& Kontradiksi Faham Keagamaan. Jakarta: Balitbang Agama dan Diklat Keagamaan.

Fuller, Graham E. 2010. A World Without Islam. New York: Back Bay Books.

Ghafur, Hanief Saha dkk. 2010. Islam Rahmatan Lil Alamiin- Buku Rujukan Guru PAI Sekolah Menengah Atas (SMA), Sekolah Menengah Kejuruan (SMK). Jakarta: Direktorat Pendidikan Agama Islam.

Ghafur, Hanief Saha dkk 2010. Islam Rahmatan Lil 'alamiin, Buku Rujukan Guru PAI Sekolah Dasar (SD). Jakarta: Direktorat Pendidikan Agama Islam

Haedari, Amin. 2011. Pendidikan Agama dan Keagamaan-Reinventing Pendidikan Islam Unggul Dan Kompetitif. Jakarta: Puslitbang Pendidikan Agam,a dan Keagamaan.

Hayat. Bahrul. 2012. Mengelola Kemajemukan Umat Beragama. Jakarta: Saadah Cipta Mandiri.

Hasani, Ismail Ismail, et al. 2011. Radikalisme Agama di Jabodetabek dan Jawa Barat: Implikasinya terhadap Jaminan Kebebasan Keragaman/Berkeyakinan. Jakarta: Setara Institute. Tim Survey. 2011. Laporan Penelitian, Ancaman bagi ideologi Negara Melalui Radikalisme Agama. Jakarta: Lembaga Penelitian Uhamka. 
Herlina. 2005. Guard The Religious Conflicts - In Strengthening National Integration. Jakarta: Balitbang dan Diklat Kementerian Agama

Malik, Muhamad. 2002. "Pluralisme Agama dan Toleransi Dalam Islam," Dialog - Jurnal Penelitian dan Informasi Keagamaan, No 54 Th.XXV, Desember

Mas'ud, Abdurrahman, (ed). 2011. Kerukunan Umat Beragama Dalam Sorotan - Refleksi dan Evaluasi 10 (sepuluh) Tahun Kebijakan dan Program Pusat Kerukunan Umat Beragama, Jakarta: Pusat Kerukunan Umat Beragama, Sekretariat Jenderal Kemenag.

Mudzhar, Mohammad Atho. 2011. Islam In A Globalized World - The Challenges of Human Rights, Law, and Interfaith Harmony, Jakarta: Badan Litbang dan Diklat Kementerian Agama.

Mudzhar, Atho. 2012. "Akar Kekerasan Dan Kekeliruan Dalam Pemahaman Sejarah Dan Keagamaan Islam". Makalah Seminar. Jakarta: Direktorat Pendidikan Agama Islam Kementerian Agama.

Peraturan Pemerintah Republik Indonesia Nomor 55 Tahun 2007 Tentang Pendidikan Agama dan Pendidikan Keagamaan. Jakarta: Direktorat Pendidikan Agama Islam pada Sekolah, Kementerian Agama.

Raharjop, Muji. 2012. Quo Vadis Pendidikan Islam, Malang: UIN-Malang Press

Sarijo, Marwan (Penyunting). 2009. Mereka Bicara Pendidikan Islam - Sebuah Bunga Rampai, Jakarta, PT Raja Grafindo Persada.

Suaedy, Ahmad. 2013. "Strategi Moderasi Atas Kecenderungan Radikalisme Agama di Indonesia: Tanggapan Terhadap Hasil Penelitian Radikalisme Agama di Kalangan Mahasiswa Perguruan Tinggi Agama. Jakarta: Puslitbang Pendidikan Agama.

Tim Peneliti Balai Litbang Agama Jakarta. 2011. Kasus-KasusAktual Kehidupan Keagamaan Studi Pencegahan Dini Konflik Umat Beragama. Jakarta: Balai Litbang Agama Jakarta.
Tim Peneliti Puslitbang Penda 2011, Penelitian Tentang Paham Keagamaan GPAI di Sekolah, Jakarta, Puslitbang Pendidikan Agama dan Keagamaan.

Tim Peneliti Puslitbang Kehidupan Keagamaan. 2011. Laporan Tahunan Kehidupan Keagamaan Di Indonesia 2011, Jakarta, Puslitbang Kehidupan Keagamaan.

Tholkhah, Imam. 2010. Ahlak dan Pendidikan Islam, Jakarta, Titian Pena.

Tholkhah, Imam (ed). 2002. Konflik Sosial Bernuansa Agama Di Indonesia, Jakarta, Puslitbang Kehidupan Beragama, Departemen Agama RI,

Tholkhah, Imam. 2008. Menghiasi Diri dengan Ahlak Mulia. Jakarta: Al Ghazali.

Tholkhah, Imam. 2008. Manusia, Agama dan Perdamaian. Jakarta: Al Ghazali.

Tholkhah, Imam. 2002. “Krisis Sosial Dan Kebangkitan Gerakan Radikalisme Keagamaan Era Reformasi Di Indonesia." Dalam Dialog- Jurnal Penelitian dan Informasi Keagamaan, no. $54 \mathrm{Th}$ XXV, Desember.

Tholkhah, Imam. 2001. Anatomi Konflik Politik di Indonesia - Belajar dari Ketegangan Politik Varian Madukoro. Jakarta: PT Grafindo Persada

Tholkhah, Imam. 2002. "Memupuk Kerukukunan dan Menepis Konflik Berbasis Masyarakat," Dalam Harmoni - Jurnal Multikultural dan Multi Religius, voluume 1, nomor 4, Oktober - Desember.

Tholkhah, Imam. 2004. "Membangun Kualitas Kerukunan Umat Beragama." Dalam Harmoni- Jurnal Multikultural dan Multireligius, Volume III, Nomor 12.

Tholkhah, Imam. 2005. Mewapadai Konflik Antar Umat Beragama. Jakarta: Badan Litbang dan Diklat Kementerian Agama

Tholkhah, Imam (ed). 2009. Pengembangan Pendidikan Agama Islam Berwawasan Multikultural, SMA/SMK, Jakarta, Direktorat Pendidikan Agama Islam pada Sekolah. 
Imam Tholkhah

Wibisono, Abd.Fatah dkk. 2010. Islam Rahmatan Lil Alamiin- Buku Rujukan Guru PAI Sekolah Menengah Pertama (SMP). Jakarta: Direktorat Pendidikan Agama Islam,
Yakin, M.Ainul. 2005. Pendidikan MultikulturalCross-Cultural Understanding untuk demokrasi dan Keadilan. Jakarta: Pilar Media 